\title{
The Success of Students' Loans in Financing Higher Education in Tanzania
}

\author{
Veronica R. Nyahende ${ }^{1}$ \\ ${ }^{1}$ Accounting School, Dongbei University of Finance and Economics, Dalian, China \\ Correspondence: Veronica R. Nyahende, Accounting School, Dongbei University of Finance and Economics, \\ Dalian, China. Tel: 86-138-8949-0851. E-mail: vericsmuta@yahoo.com; venicerobert1@gmail.com
}

Received: February 10, 2013 Accepted: March 31, 2013 Online Published: May 20, 2013

doi:10.5539/hes.v3n3p47

URL: http://dx.doi.org/10.5539/hes.v3n3p47

\begin{abstract}
Students' loans in financing higher education in Tanzania have been subjected to many researches. However, less information is available on how the success of students' loans in financing higher education can be revealed. Therefore the purpose of this study is to examine the factors indicating the success of students' loans in financing higher education in Tanzania.

Using data collected from a larger cross sectional survey in Tanzania, this study found that students loans in financing higher education in Tanzania is successful as it increases enrollment of students in higher learning institutions, the study also revealed that Higher Education Students' Loans Board (HESLB) is employing enough efforts to recover loans granted to loans beneficiaries since 1994 as well as the guidelines and criteria for granting loans was found to be satisfactory.

The study recommend that, enrollment decision making has been affected by other factors other than a successful students' loan financing, these factors includes political factors, economical factors, family influences and school impacts. Therefore for better understanding of the successful students' loans financing in Tanzania these factors need to be considered too. To ensure more effective recovery of already issued students loans since 1994, HESLB is recommended to institute a sound financial management which include setting appropriate interest rates to cover inflation in order to maintain the capital value of the loan fund and covering administrative costs as well as presence of adequate legal framework to ensure that students' loans are legally enforceable to reduce default among loan beneficiaries. Guidelines and criteria should be improved to be more effective such as the inclusion of economics factors to measure the economic ability among loans applicants for instance presence of collateral security.
\end{abstract}

Keywords: students loan, higher education, repayment, enrollment, guideline and criteria

\section{Introduction}

Students' loan programmes now exist in many developed and developing countries. Examples of student loan programmes which are financed from public funds or backed by government guarantees, were found in Japan, Scandinavia and the U.S.A., where the idea of students borrowing from government funds to finance higher education dares from the 1940s and 1950s (Woodhall, 2007). Other developed countries set up loan programmes in the 1960s, including Canada and several European countries.

The first developing country to establish a student loan programme was Colombia, where the Instituto Colombiano de Credito Educativo y Estudios Technicas en el Exterior (ICETEX) was established in 1953, and it was followed by many other student loan programmes in Latin America in the 1950s and 1960s, (World Bank, 2008a). By early 1980s student loan programmes were established in Europe, North America, Latin America, the Caribbean, and few isolated examples in Africa and Asia. A review of international experience of student loan programmes found official loan programmes that are run by government agencies or backed by government guarantees in more than thirty countries, (World Bank, 2008b). Loan have recently been proposed in several other countries, including the U.K., and New Zealand among developed countries, and Tanzania, South Africa, Kenya, Uganda among the developing countries.

The plan of this paper is as follows: Section 2 will cover the literature review, section 3 will be on the methodology used in the study, section 4 will cover the findings and discussion, section 5 will cover the 
conclusion and recommendations and section 6 will indicate the limitations and directions for the future research.

The purpose of this paper is to examine the students' loan in financing higher education in Tanzania by considering how the students' loans programme is successful in financing higher education. In light of the theoretical debates about students loans the paper examines the increase in the enrollment of students in higher learning institutions as a result of availability of students loans, repayment of the borrowed fund to make fund available to be re lend to other needy students and the presence of effective and sound eligibility criteria and guidelines for granting loans as the key factors for a successful students' loans in financing higher education students in Tanzania.

\subsection{Financing of Higher Education in Tanzania}

According to United Republic of Tanzania (2007) students' loans in financing higher education in Tanzania resulted due to cost sharing policy which existed during the colonial period and in post independence Tanzania. However, after independence, students in higher learning institutions paid tuition fees and students from poor families were assisted through government bursaries. In 1974, the government abolished the bursary system and assumed all the responsibilities of paying for all higher education costs for students admitted in public higher education institutions, (United Republic of Tanzania [URT], 2007).

The government failed to finance free public higher education in addition to all of the other pressing public needs, so the reinstatement of cost sharing policy in higher education was made in 1980's.The formal announcement of the policy was made in January 1992, it was argued that the introduction of cost sharing in higher education had become necessary in order to maintain the quality of academic programs, to encourage needy students to attend higher education, and to improve access to higher education, while at the same time containing government expenditures in higher education (URT,2005).

According to URT(1998),cost sharing policy in higher education was planned to be implemented in three phases, (1) in 1992/1993,students and parents were required to pay for their transportation costs to and from their respective universities, (2) in 1994/1995 students were required to pay for meals and accommodations, in addition to the first phase items, through a loan which was administered by the government to all Tanzanian students admitted in public accredited higher education institutions, (3) in 2004/2005, parents and students were required to meet partial payments through loans to cover the following additional costs; tuition fees, books and stationery, special faculty requirements, field practical training and research. Under this phase all the activities were under the supervision of the higher education students' loans board, (URT, 2005).

\subsection{HESLB and Its Establishment}

Higher education students' loans board (HESLB) was established under the act of parliament No. 9 of 2004, as amended by act No. 9 of 2007, CAP 178 and commenced its operation in July, 2005 (Higher Education Students' Loans Board [HESLB], 2008). The board was established following the adoption of the national higher education policy of 1999. Among other things, the board has been entrusted by the government with the responsibility to disseminate loans to Tanzanian students who are eligible and needy as defined by the act No. 9 of 2004 pursuing advanced diplomas and or degree studies at accredited higher learning institutions in and outside the country and to collect repayment for all loans issued to students since 1994, so as to make the scheme successful, (HESLB, 2006).

Ishengoma (2004) argue that since the introduction of HESLB, there is an increase in access of the needy students to higher learning institutions due to increase in students enrollment which has been proved by the increase in number of universities or colleges as shown in Table 1. Before the introduction of students loans programme there were only 11 public universities and university colleges as well as 19 private universities and colleges, (Tanzania Commission for Universities [TCU], 2009). 
Table 1. Distribution of higher education institutions in Tanzania based on ownership

\begin{tabular}{|c|c|c|c|c|}
\hline \multirow[t]{2}{*}{$\mathrm{S} / \mathrm{N}$} & \multirow[t]{2}{*}{ REGION } & \multicolumn{3}{|c|}{$\begin{array}{l}\text { NUMBER OF HIGHER EDUCATION } \\
\text { INSTITUTIONS }\end{array}$} \\
\hline & & PRIVATE & GOVERNMENT & TOTAL \\
\hline 1. & Dar Es Salaam & 5 & 16 & 21 \\
\hline 2. & Morogoro & 1 & 2 & 3 \\
\hline 3. & Arusha & 3 & 2 & 5 \\
\hline 4. & Iringa & 2 & 2 & 4 \\
\hline 5. & Dodoma & 1 & 2 & 3 \\
\hline 6. & Mwanza & 2 & - & 2 \\
\hline 7. & Mjini magharibi (Zanzibar) & 1 & 1 & 2 \\
\hline 8. & Kusini Unguja (Zanzibar) & 1 & 1 & 2 \\
\hline 9. & Kigoma & 1 & - & 1 \\
\hline 10. & Tanga & 1 & - & 1 \\
\hline 11. & Kilimanjaro & 4 & 1 & 5 \\
\hline \multirow[t]{2}{*}{12.} & Mbeya & 1 & 1 & 2 \\
\hline & TOTAL & 23 & 28 & 51 \\
\hline
\end{tabular}

Source: TCU (2009)

Table 1. indicates the increase in number of universities and colleges in Tanzania as results of the introduction of higher education students' loans programme through HESLB to support higher education students in Tanzania.

\subsection{General Objectives}

The general objective of this paper is to examine the factors indicating the success of students' loans in financing higher education in Tanzania.

\subsubsection{Specific Objectives}

The specific objectives include:

(1) To assess the increase in students enrollment attributed by students' loans.

(2) To evaluate the performance of HESLB in recovering students' loan from beneficiaries since 1994.

(3) To assess the eligibility criteria and guidelines for granting students loans.

\subsubsection{Research Questions}

(1) Has the students' loan increased the number of students' enrollment in higher learning institutions in Tanzania?

(2) Does HESLB employ enough efforts to recover loans granted to beneficiaries since 1994 ?

(3) Does the eligibility criteria and guidelines for granting loans satisfactory to needy Tanzanian students?

\section{Literature Review}

\subsection{Human Capital Theory and Students' Loans}

Barr (2009) argue that according to Human Capital theory expenditure on education is treated as an investment and not as a consumer item. An individual acquires this human capital in schooling and post-school investment and on the job training. Efforts are made in Tanzania to encourage cost sharing and loan scheme in order to increase number of educated people because it is believed that highly trained and skilled manpower is the pivotal element for real development and the government is undertaking this approach because it believes in human capital theory, (Ishengoma, 2004). Schultz (1963) supports the theory by saying that “...Increase investment in human capital increases individual productivity and income, and concurrently lays the technical base for the type of labour force necessary for economic growth in modern industrialized society".

Research by Snooks (2008) support that there has been increasing awareness that, human capital when combined 
with other factors of production can be an important factor in economic development. This study also agrees on human capital theory because of the belief that people constitute the most important resource in any organization. It is people who act on other resources such as money, machines, materials and methods that enable organization to function. Robbins (2009) also argues that organization can survive without other resources, but they cannot survive without people. For organizations to achieve good end result, much of the investment must be directed on human being.

Students' loans will encourage more students to get education through increased enrollment, loan recovery should be emphasized in order to finance other needy and qualified students, guidelines and selection criteria should be effective for the success of the students' loans in financing higher education in Tanzania.

\subsection{Students' Enrollment Decision Making Process}

According to Heller (2008) students' enrollment is the act of enlisting in a program or course or the state of being registered for a program or course. Research by Avery and Hoxby (2004) support that enrollment has been guided by the enrollment management which is systematic set of activities designed to enable educational institutions to have influence over their students' enrollments. It guides institutional practices in new students recruitment and financial aid through students' loans, students retention and other academic areas that affect enrollments and students outcomes from college, (Callender \& Jackson, 2005). Most recent empirical research on enrollment decision into higher education as a result of availability of students aids have been done in United States where as in other countries like Tanzania this topic has remained unexplored so far, (Baumgartner \& Steiner, 2005).

Baumgartner and Steiner (2006) argue that decision making in enrollment is a complex process affected by political factors, economic factors, cultural factors, family influence and school impact. On the other hand research by Somers, Haines and Keene (2006) supports that it is believed that the effect of students' loans on college enrollment is mediated by family background for example parents' level of education, by higher education institutions themselves and by social, economic and political environment. Streitfeld (2009) concludes that increasing unemployment and economic downturn have lead to the increasing college enrollment ranging from 2 percent to 27 percent in the United States. However the growth in students' loans in recent years indicates that more families are relying on loans to finance their children's higher education, (Callender \& Jackson, 2005).

According to Barr (2009), most financial aid research are based on the economic theory of human capital, the theory states that students makes decision on college enrollment based on expectation of the lifetime benefits and costs of enrollment such that it maximizes their utility. On the other hand Heller (1997) criticize the human capital theory that, it is insufficient by itself as it gives misunderstanding concepts on how financial aid influences students' college enrollment decisions, for example it does not explain why students react differently to various forms of financial aids given the same economic value.

More studies on how students respond to financial aid availability and the decision made on enrollment has been done by Niu and Tienda (2008), the study was referred to as students price responsiveness. Survey and case study was used for data collection, the study came out with some tenets regarding higher education policy that, (1) higher education is like most goods and services in our economy, other things being constant individuals are likely to consume less of it given the price rise, (2) higher education is a normal good, other things being constant as real income rise, more students will enroll in college. Moreover, effective guidelines and criteria governing the students' loans has been supported by Baum and McPherson (2008) as the factor influencing increased enrollments among students. However research by Mundel (2008) indicates that students' loans have a minimal effect on the increase in students enrollment compared to grants which have a positive effect on college access and choice.

According to Somers et al (2006) more families are relying on students' loans to finance their children's higher education, which is especially true in Tanzania. Therefore students' loans finances in Tanzania is successful in its operations as it increases enrollment among students, there is presence of a sound guidelines and criteria also there is availability of revolving fund obtained through repayment of already issued students' loans.

\subsection{Success and Failure of Students' Loans in Financing Higher Education}

Johnstone (2006a) argues that success and failure of students loans in financing higher education is embedded on the philosophy or assumptions as well as the strong appeal which the students' loans is based on. That is that students' loans in financing higher education are based on a questionable philosophy and unrealistic assumptions and are being launched in many developing countries with exaggerated expectations (Johnstone, 2006b).

According to Johnstone (2006c) the major expectations of governments with regards to student loan finances are: 
(1) huge funds can be mobilized in a short time, with the repayments of loans by the graduates (2) government can do away with budgetary allocations for higher education and eventually withdraw from financing higher education and (3) higher education can be made self-financing with the revolving fund.

All the three assumptions stated are basing on the recovery of the already issued students' loans by insisting that the loanees will repay back their due loan automatically without any resistance. According to Berlinger (2009), the truth is, much effort is needed for the loan beneficiaries to repay back the loans given, for instance the use of loan repayment education campaign as well as the use of loan collectors agent as it is done in the case of Tanzania. Other variables such as the satisfactory guidelines and criteria for granting loans as well as the increased enrollment of students to higher education have not been taken care by the philosophies. Therefore the failure of students' loans in financing higher education is a result of reliance on the above mentioned unrealistic and questionable philosophies.

According to Richard (2002), the success of students' loans in financing higher education is a results of the strong appeal embedded on students' loans itself, these appeals are based on the increased enrollment of higher education students, satisfactory guidelines and criteria for granting loans as well as the recovery of already issued students loans funds.

Research by Johnstone and Marcucci (2010) support that students' loans not only increase access to higher education but also, more importantly, reduce regressive distribution of public resources this is because all those who get students loans for their education are the one who will be obliged to pay the loan. However Msolla (2007) argue that satisfactory guidelines and criteria for granting loans has been strongly appealed as they prevent wasteful expenditures as only the needy will get loans. Moreover students loans are regarded as equitable as they appear to hold out the promise to the student that, 'you can borrow money when you cannot pay for higher education on your own and repay when you can' this advocates the recovery of the already issued students' loan, (Macmillan, 2006).

The success of students' loans in financing higher education in Tanzania has been achieved as it has been explained by the increased enrollment, the presence of satisfactory guidelines and criteria for granting loans as well as the continuing recovery of the already issued students' loans since 1994.

\subsection{Empirical Evidence on Students' Loans World Wide}

According to Johnstone and Marcucci (2009) several countries in Western Europe and Asia were introducing reforms in student support system in the 1990s due to: increasing cost and inadequacy of existing systems of student aid, changes from highly selective systems of higher education to mass higher education and desire to expand higher education participation without imposing an excessive burden on public fund.

Yang (2006) did a research in Asians countries, where by the results show that financial pressure on public budgets experienced by Asian countries has led many governments to seek ways to increase private contributions to the cost of higher education. For instance Japan and Philippines use private finance to attend private institutions, while in China and India higher education is financed mainly by the state (Li, 2007). According to Woodhall (2002b) most of the other countries in Asia students get financial support in the form of scholarships, grants and loans, though the concern about equity advocates that loans will result in more equitable sharing of the cost of higher education than a system of grants, scholarship and free tuition fee, financed from government revenue, (Woodhall, 2007).

A study on how the students' loans scheme can be sustainable through repayment was conducted in South Africa by Jackson (2002), the results explains that national student financial assistance scheme (NSFAS) is being and remaining sustainable due to recovery of the loan portion of the award from students and recycling of these funds back to the scheme in order to assist future generation students. In 1991 a small scheme to assist black disadvantaged students were established in South Africa named as NSFAS (Varghese, 2006). The scheme has grown into a national scheme which has helped to finance the cost of higher education for over 600,000 black needy students and academically qualified. NSFAS is funded by the government contributions, donors and is increasing its share from loan repayments by former students, (Jackson, 2002).

Varghese (2006) continue to argue that Kenya has a long history of experimenting cost sharing in higher education, it started in 1952 when loans were given to students to study abroad, whereby students started getting bursaries and grants in 1963. According to Woodhall (2002a) the government introduced the university students' loans scheme, managed by the ministry of education in 1974 to take care of the increased demand in higher education but there were no recovery due to lack of legal framework. Johnstone (2006c) argue that the Kenyan government established the higher education loans board (HELB) in 1995 with mandate to disburse funds and 
recover the outstanding loans since 1952 so as to create a viable revolving fund, which could generate substantial turnover through interest to be lent to the needy students so as to ease pressure on the national educational budgets.

According to HESLB (2004) in Tanzania higher education students are financed through the loans given by the government through the higher education students' loans board (HESLB) which is a body corporate established under the Act number 9 of 2004, as amended by Act number 9 of 2007 CAP 178. HESLB became operational in April 2005 with the objective of assisting on loan basis the needy Tanzanian students who secure admission in accredited higher learning institutions, but have no economic power to pay for the cost of their education, (HESLB, 2004).

According to World Bank (2009), students' loans in financing higher education has been experienced worldwide by several countries to foster the fast growth of higher education participation hence growth in the countries' economy as a whole. Students' loans needs to be successful for its better performance by increasing students' enrollment, having sound and easy to go with guidelines and criteria for granting loans as well as recovery of the already issued loans should be insisted to ensure availability of fund to be re lend to other needy students.

\subsection{Theoretical Framework}

As discussed in the literature reviewed and cemented by theory, the theoretical framework in Figure 1. has been developed to present the relationship between the successful students' loans in financing higher education and the increased students' enrollment, satisfactory guidelines and criteria for granting students' loans and the effective recovery of the already issued students' loans since 1994.

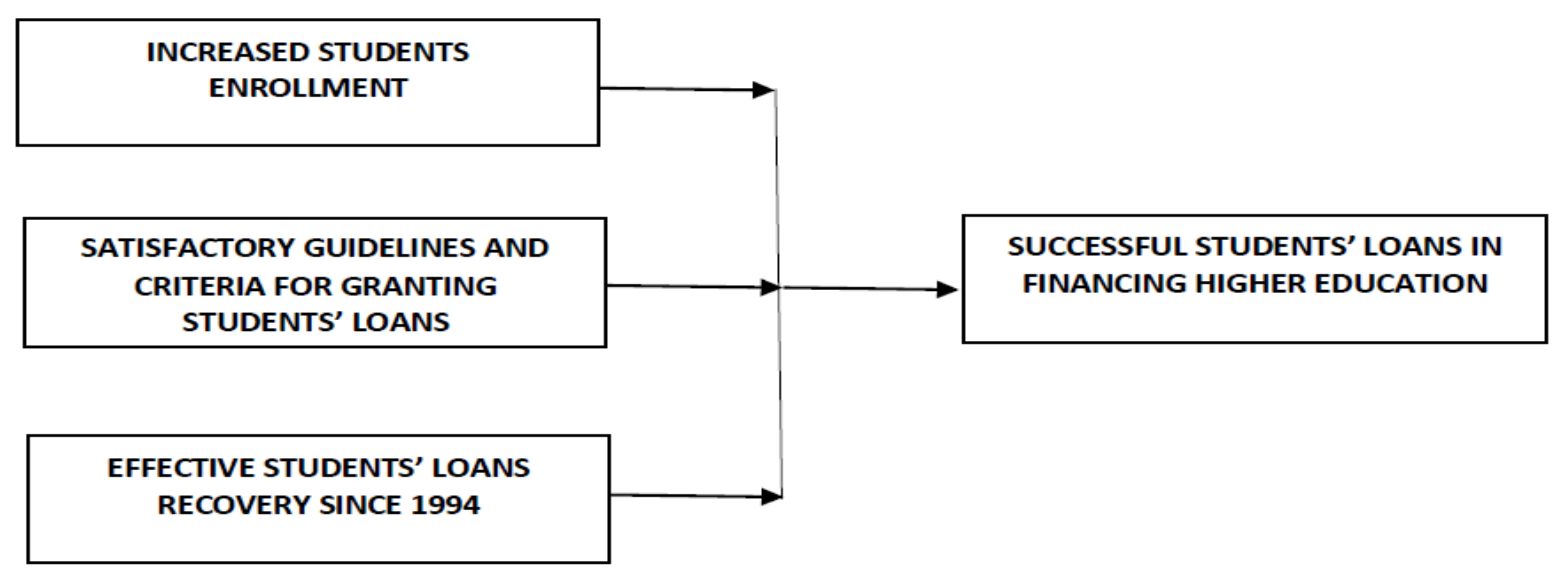

Figure 1. Theoretical framework of this study

Figure 1. Leads to a conclusion that the successful students' loans in financing higher education in Tanzania depends on having satisfied the variables mentioned. Therefore students' loans finances of higher education in Tanzania is successful because it leads to increased enrollment, there is presence of sound and satisfactory guidelines and criterias for granting loans also there is revolving fund created through recovery obtained from loanees since 1994.

\section{Methodology}

\subsection{Research Design}

A descriptive cross sectional research design was used. Cross sectional studies involves study of a particular phenomenon (or phenomena) at a particular time. According to Saunders and Thornhill (2007) a descriptive study is concerned with either determining the frequency with which something occurs or relationship between variables. The research was guided by questionnaires in collection of data .To successfully carry out the research, both desk and field research was applied.

\subsection{The Population, Sample Size and Sampling Procedures}

\subsubsection{Population and Sample Size}

The population of this study includes students who are loan beneficiaries from accredited higher learning 
institutions in Tanzania. The study was conducted in university of Dar es salaam (UDSM), University of Dodoma (UDOM), Mzumbe University (MU), Tumaini University Dar es Salaam College (TUDARCO) and Saint Augustine University of Tanzania (SAUT). The long establishments of these universities merited the availability of many respondents as the universities attract a lot of students due to its long experience in the enrollment of students supported by students' loans.

Sample of 1101 respondents were used by the researcher expediently after being verified by the researcher of their availability. A sample of 1101 students comprises of 382 from UDSM, 253 MZUMBE, 227 UDOM, 65 SAUT and 174 TUDARCO. The sample from each cluster were obtained from a list of enrolled students obtained from Tanzania commission for universities (TCU). The researcher need to satisfy herself of the availability of the students because the researcher was aware that some of the enrolled students might be dropped out or they may not be in the college at the time of data collection for some other reasons such as sickness.

Larger survey was used because of the nature of the study itself, the study indicates that better results could be achieved by examining the behaviour of large populations of students rather than a relatively small number of students. The researcher was interested to get more accurate results while minimizing the level of biasness which could be introduced by the use of large survey. The success of students' loans in financing higher education is of importance in Tanzania due to inability of most students to pay for higher education. So the researcher used the larger survey so as to accommodate the ideas and contributions from a wide range of students on how they assess the success of the financial assistance provided by the availability of students loans by taking into account the enrollment, repayments as well as the soundness of the guidelines and criteria for granting loans, suggestions for improvement was also sought by the researcher.

\subsubsection{Sampling Procedures}

Names of students who are loans beneficiaries were obtained from Tanzania commission for universities (TCU), whereby the list of enrolled students from each higher learning institution mentioned were obtained in respect of year 2004/2005, 2005/2006, 2006/2007, 2007/2008. The register comprises of the names of the enrolled students who are government sponsored through students' loans scheme in Tanzania.

Sampling procedures used was cluster sampling and purposive sampling techniques. Using cluster sampling five universities the UDSM, MZUMBE, UDOM, SAUT and TUDARCO were randomly selected by the researcher to form a group of five clusters. In each cluster homogeneous sampling of purposive sampling procedure was used where by the researcher used the personal judgment to choose a sample to be used in the study. Despite the fact that purposive sampling is prone to researcher's bias, the researcher find convenient to use it, this is because the population within each cluster consists of the same characteristics, for example they are all students as well as they are all loans beneficiaries.

\subsection{Data Collection}

This study obtained quantitative data from both primary and secondary data, (1) using primary data the researcher obtained the information on how the loans beneficiaries perceive the organization (HESLB) in term of efficiency, information on individual interpretations on policies or procedures governing the students loans scheme. For example they were asked whether HESLB is employing enough effort in recovering loans since 1994, whether eligibility criteria and guidelines are valid, sound and satisfactory and how the concept of success of students' loans scheme in financing higher education is seen by loans beneficiaries as measured by the increased students enrollment, recovery of already issued loans and the soundness of the eligibility criteria and guidelines for granting loans (2) from Secondary data the researcher obtained information concerning strategies, challenges, opportunities and performance of students' loan scheme to assess its success, review of students applications forms to see the number of students applied for loans and compare them to the enrolled list obtained from TCU. Review of policies and procedural documents concerning loans provision and repayment to see whether the procedures are being followed and whether there is some effort made to arose the interest of loans beneficiaries to repay back the loans given.

\subsection{Data Analysis}

Data collected from questionnaires, interviews and documentary review were subjected to content analysis. The researcher were interested to find a link between success of students loans in financing higher education in Tanzania and the increased enrollment, loan recovery and the presence of a sound guidelines and criteria for granting loans. The results from content analysis were presented in numbers and percentages after being coded, counted, weighted and presented into a percentages for drawing conclusions. 


\section{Findings and Discussion}

The goal of this study was to determine the success of students' loans in financing higher education in Tanzania. In particular the researcher were interested in knowing the students' perceptions on the criteria and guidelines for granting loans, assessing the effort employed by HESLB to ensure recovery of loans in respect of loans given out since 1994 as well as assessment of the increased students' enrollment since the establishment of HESLB in year 2004/2005. In guiding this investigation the following research questions were used:

(1) Has the students' loans increased the number of students' enrollment in higher learning institutions in Tanzania?

(2) Does HESLB employ enough efforts to recover loans granted to beneficiaries since 1994 ?

(3) Does the eligibility criteria and guidelines for granting loans satisfactory to the needy Tanzanian students?

\subsection{Investigation of the Impact of Students Loans Fund on Students Enrollment in Higher Education Institutions}

The research question on this objective was answered by collecting data through documentary reviews, i.e., the students' enrollment register. The study covered five higher learning institutions that have enrolled students who are students' loans beneficiaries. These institutions are the UDSM with 12,144 enrolled students in year $2004 / 2005,15,081$ in year 2005/2006, 18,393 in year 2006/2007, 21,156 in year 2007/2008. MU with 2,550 enrolled students in year 2004/2005, 3,210 in year 2005/2006, 3,474 in year 2006/2007, 4,437 in year 2007/2008. UDOM, with 116 enrolled students, which is the first enrollment in year 2007/2008, SAUT with 657 enrolled students in year 2004/2005, 1,344 in year 2005/2006, 2,665 in year 2006/2007, 4,165 in year 2007/2008 and TUDARCO with 286 enrolled students in year 2004/2005, 264 in year 2005/2006, 1,350 in year 2006/2007, and 1328 in year 2007/2008.

After reviewing the document on the enrolled register a researcher came out with the conclusions as shown in Table 2.

Table 2. A summary of students enrollment in the selected universities

\begin{tabular}{|c|c|c|c|c|c|c|c|c|c|c|}
\hline \multirow[t]{2}{*}{ INSTITUTION } & \multicolumn{2}{|c|}{$2004 / 2005$} & \multicolumn{2}{|c|}{$2005 / 2006$} & \multicolumn{2}{|c|}{ 2006/2007 } & \multicolumn{2}{|c|}{$2007 / 2008$} & \multicolumn{2}{|c|}{$\begin{array}{c}\text { TOTAL } \\
\text { ENROLLMENT }\end{array}$} \\
\hline & No. & $\%$ & NO. & $\%$ & NO. & $\%$ & NO. & $\%$ & No. & $\%$ \\
\hline UDSM & 12144 & 18.19 & 15081 & 22.59 & 18393 & 27.54 & 21156 & 31.68 & 66774 & 100 \\
\hline MZUMBE & 2550 & 18.65 & 3210 & 23.48 & 3474 & 25.41 & 4437 & 32.46 & 13671 & 100 \\
\hline UDOM & 0 & 0 & 0 & 0 & 0 & 0 & 1116 & 100 & 1116 & 100 \\
\hline SAUT & 657 & 7.44 & 1344 & 15.22 & 2665 & 30.18 & 4165 & 47.16 & 8831 & 100 \\
\hline TUDARCO & 286 & 8.86 & 264 & 8.18 & 1350 & 41.82 & 1328 & 41.14 & 3228 & 100 \\
\hline
\end{tabular}

Source: TCU (2009)

Table 2. indicates that since the introduction of HESLB to provide students loans support to needy students in 2004/2005, the students enrollment has been increased by 13.49\% in UDSM from year 2004/2005 to year 2007/2008. At MZUMBE the enrollment of students has increased by $13.81 \%$ for year $2004 / 2005$ to year $2007 / 2008$. SAUT indicates the increase in enrollment by $39.72 \%$ from year $2004 / 2005$ to year $2007 / 2008$ and TUDARCO represents the increase of students enrollment by $32.28 \%$ for year $2004 / 2005$ to year $2007 / 2008$. The results also indicates the increase of female students enrollment by $2.44 \%$ for year 2005/2006 to year 2007/2008 in respect of UDSM, MZUMBE, UDOM, SAUT and TUDARCO (Appendix I). Therefore the researcher conclude that the students loans is successful in financing higher education in Tanzania because there is an increase in students enrollments since the introduction of students loans programme.

\subsection{Efforts Employed by HESLB to Recover Loans Granted to Beneficiaries since 1994}

To understand whether enough effort has been employed by HESLB to recover loans granted to beneficiaries since 1994, questionnaires were distributed among the enrolled students obtained in each university to understand whether HESLB has been educating them on their obligations to repay back the loans, by arousing their interest toward loan repayments. Also the researcher needs to know the willingness of the students' loans beneficiaries to repay back the loan after study completion. Questionnaires were distributed to 1101 students and the results were as shown in Table 3. 
Table 3. Students response about willingness to repay the loans

\begin{tabular}{lcccccccccccc}
\hline & \multicolumn{2}{c}{ UDSM } & \multicolumn{2}{c}{ MZUMBE } & \multicolumn{2}{c}{ UDOM } & \multicolumn{2}{c}{ SAUT } & \multicolumn{2}{c}{ TUDARCO } & \multicolumn{2}{c}{ TOTAL } \\
& NO & $\mathbf{\%}$ & NO & $\mathbf{\%}$ & NO & $\mathbf{\%}$ & NO & $\mathbf{\%}$ & NO & $\mathbf{\%}$ & NO & $\%$ \\
\hline Yes & 354 & 92.7 & 219 & 86.6 & 188 & 83 & 53 & 82 & 130 & 75 & 944 & 83.6 \\
No & 28 & 7.3 & 34 & 13.4 & 39 & 17 & 12 & 18 & 44 & 25 & 157 & 16.4 \\
Total & 382 & 100 & 253 & 100 & 227 & 100 & 65 & 100 & 174 & 100 & 1101 & 100 \\
\hline
\end{tabular}

Source: Field data (2012)

The results in Table 3. indicates that more than three quarter of the students from UDSM, MZUMBE, UDOM, SAUT and TUDARCO respectively were willing to repay back the loans after study completion and only quarter of the students were unwilling to repay back. Of the three quarter of the students a greater percentage which is $92.5 \%$ is composed of the students from UDSM while a smaller percentage of $75 \%$ was formed by students from TUDARCO this is a result of a long establishment of UDSM back to 1974 hence the knowledge about students' loans, its importance and the obligation to repay loans have been long imparted to students, so it becomes a culture to the university itself to repay the loans given compared to other university for example UDOM and TUDARCO which were established in year 2007 and year 2003 respectively(TCU,2009). However a big number of students who are loans beneficiaries considered in this study is from UDSM.UDSM and HESLB are all situated at Dar es salaam city hence UDSM is easily accessible by HESLB official for all matters concerning repayment of already issued students loans fund since 1994.Therefore a high percentage of the enrolled students in respect of those universities under study are willing to repay back the students loans after completion of the study, the researcher is believing that they have been educated by HESLB to understand their obligation to repay back the loans given. Therefore students loans is successful in financing higher education in Tanzania as HESLB is employing enough effort to recover the issued students loans since 1994.

\subsection{Guidelines and Criteria for Granting Loans in the Academic Year 2007/2008}

To assess on how the students' loans beneficiaries evaluate the guidelines and criterias for granting students' loans as issued by HESLB. Questionnaires were distributed to 1101 students to test on the effectiveness of guidelines and criteria for granting loans, the results were as shown in Table 4.

Table 4. Students response on the guidelines and criteria for granting loans in the academic year 2007/2008

\begin{tabular}{lccccccc}
\hline Response category & \multicolumn{4}{c}{ Selected Institutions } & \multicolumn{2}{c}{ Total } & \multicolumn{2}{c}{$\begin{array}{l}\text { Percentage } \\
\end{array}$} & UDSM & MZUMBE & UDOM & SAUT & TUDARCO & $\begin{array}{l}\text { Respondents } \\
\text { (\%) }\end{array}$ \\
\hline Very effective & 20 & 13 & 16 & 3 & 0 & 52 & 4.72 \\
Effective & 74 & 35 & 19 & 7 & 16 & 151 & 13.71 \\
Satisfactory & 170 & 146 & 115 & 29 & 123 & 583 & 52.95 \\
Poor & 102 & 41 & 59 & 22 & 29 & 253 & 22.98 \\
Segregative & 15 & 19 & 18 & 4 & 6 & 62 & 5.64 \\
TOTAL & 382 & 253 & 227 & 65 & 174 & 1101 & 100 \\
\hline
\end{tabular}

Source: Field data (2012)

Table 4. indicates that a half of the students respondents from UDSM, MZUMBE, UDOM, SAUT and TUDARCO have categorized HESLB guidelines and criteria for granting loans in the academic year 2007/2008 to be satisfactory, the other half is being shared among very effective, effective, poor and seggregative categories respectively. Satisfactory category was ranked higher than other categories, this indicates that students loans is successful in financing higher education as it is being supported by a satisfactory guidelines and criterias for granting loans in year 2007/2008. 


\section{Conclusions and Recommendations}

\subsection{Conclusion}

Students enrollment in higher learning institutions in Tanzania had increased as a result of the availability of students' aids through students' loans. The number of students granted loans had increased hence posed a challenge to HESLB to recover loans granted to beneficiaries since 1994 so as to bridge the gap between government subvention and the increasing funds requirements. All five higher learning institutions selected by the researcher, showed significant increase in student's enrollment in every academic year. Hence the successful students' loans finances has increased the number of student's enrollment.

Students loans beneficiaries are willing to repay back the loans after completion of their studies. HESLB did a lot to ensure recovery of students' loans given out since 1994, through review of strategies for HESLB loan repayment and recovery which includes, enhancement of public awareness in respect of loan repayment, publishing names of untraced loan beneficiaries, follow-up on job vacancies advertised in print media and enforcing loan repayment in the mindset of students beneficiaries and their employers, these results into a successful students loans in financing higher education because of the availability of revolving fund created through repayment to be given out to other needy students

HESLB guidelines and criteria for granting loans in the academic year 2007/2008 are satisfactory hence they are favourable to loans beneficiaries because they are attainable and can easily attract and accommodate prospective Tanzanian students. Due to that, the guidelines and criteria had increased number of students granted loans as well as enrollment of students in higher learning institutions which also enhance the success of the students' loans in financing higher education in Tanzania.

\subsection{Recommendations}

HESLB should institute a sound financial management including setting appropriate interest rates to cover inflation, thus maintaining the capital value of the loan fund and covering administrative costs. This should be done in additional to the awareness campaign on obligation to repay which is proved to be done in this study, as it resulted into a big proportional of respondents being willing to repay back the loans. Other measures to ensure effective recovery by HESLB includes adequate legal frameworks to ensure that loan recovery is legally enforceable and effective loan collection machinery, using either commercial banks or engagement of debts collectors to ensure high rates of repayment and to minimize default.

Guidelines and criteria for granting loans should be improved to include the assessment of economic status of students' loans applicants, because the economic status will determine their ability to repay back the loans. Students must have the willingness and ability to repay back the loans for a successful students' loans finance in Tanzania. Therefore things like collateral security should be considered during loans application.

Students' enrollment decision making has been also affected by political factors, economic factors, cultural factors, family influence and school impact which are not part of this study. Therefore these factors needs to be considered for a successful students' loans financing for example economic downturn and increased unemployment have lead to the increase in students' enrollment.

\section{Limitations and Direction for Future Research}

The paper focused only on five universities in Tanzania, so the future studies should expand to cover more universities in Tanzania to make the study more general and more applicable to other countries. The paper indicates that woman has a small proportional of attendance in higher learning studies as it has been presented by small percentages of enrollments compared to men, therefore future studies should focus on the success of students' loans in financing women in higher education in Tanzania. The study focused on students' loans as the only factor influencing college enrollment decision making but some literatures revealed other factors influencing decision making on students enrollment, for example the economic factors. Therefore future study should focus on the effects of economic factors on the students' enrollment decision making.

\section{Acknowledgements}

I would like to thank Prof Chen Yan my supervisor, for devoting her time in providing me with genuine knowledge about my research area, regular supervision and constructive comments which are the basis for this article, also to my fellow students Ms. Lucy Kiute of Dongbei University of Finance and Economics, Ms. Upendo Kadikos of Dalian Maritime University and Mr. Marco Kung'unde of Dalian university of Technology for their endless support towards my studies in developing this article. 


\section{References}

Avery, C., \& Hoxby, C. M. (2004). Do and should financial aid packages affect students' college choices? In C. M. Hoxby (Ed.), College choices: The economics of where to go, when to go, and how to pay for it. Chicago: University of Chicago Press. http://dx.doi.org/10.7208/chicago/9780226355375.003.0007

Barr, N. (2009). Financing higher education lessons from economic theory and reform in England. A special issue of Higher education in Europe, 34(2), 201-210.

Baum, S., \& McPherson, M. (2008). Introduction. In S. Baum, M. McPherson, \& P. Steele (Eds.), The effectiveness of student aid policies: What the research tells us. Washington, DC: The College Board.

Baumgartner, H. J., \& Steiner, V. (2005). Student Aid, Repayment obligations and enrollment in higher education in Germany. Evidence from a National experiment Schmollers Jahrbuch, 125(1), 29-38.

Baumgartner, H. J., \& Steiner, V. (2006). Does more generous student aid increase enrollment rate into higher education? Evaluating the German student aid reform of 2001. IZA Discussion papers No.2034. Retrieved from http://ssrn.com/abstract=892831

Berlinger, E. (2009). An efficient student loan system: Case of Hungary. A special issue of Higher education in Europe, 34(2), 257-268.

Callender, C., \& Jackson, J. (2005). Does the fear of debt deter students from higher education? Journal of Social Policy, 34.

Heller, D. E. (1997). Student price response in higher education: An update to Leslie and Brinkman. Journal of Higher Education, 68. http://dx.doi.org/10.2307/2959966

Heller, D. E. (2008). The impact of student loans on college access. Chapter 3. In S. Baum, M. Mcpherson, \& P. Steele (Eds.), The effectiveness of student aid policies: What the research tells us. Washington, DC: College Board.

HESLB. (2004). Act number 9 of 2004 CAP 178, Dar es salaam, Tanzania Parliament.

HESLB. (2006). Annual Report, 2005 - 2006, Dar es salaam, Higher education students' loans board.

HESLB. (2008). Corporate strategic plan 2008-2011. Dar es salaam, Higher education students' loans board.

HESLB. (2009). Published guidelines and criteria for granting loans in the academic year 2007/2008, Dar es salaam, Higher education students' loans board.

Ishengoma, J. M. (2004). Cost sharing and Participation in Higher Education in Sub-Saharan Africa: The case of Tanzania (Doctoral dissertation). State University of New York at Buffalo.

Jackson, R. (2002). The National Student Financial Aid Scheme of South Africa (NSFAS): How and why it works. The Welsh Journal of Education Special International issues, 11(1), 82-94.

Johnstone, D. B. (2006b). Higher educational Accessibility and Financial viability; The Role of Student loans in Higher education in the world: The financing of universities. Barcelona: Palgrave Macmillan.

Johnstone, D. B. (2006c). Financing Higher Education: Cost-Sharing in International Perspective: Center for International Higher Education Lynch School of Education. Boston College Chestnut Hill, Massachusetts.

Johnstone, D. B., \& Marcucci, P. (2010). Financing higher educaton in International perspective: who pays? Who should pay? Baltimore: The Johns Hopkins University Press.

Johnstone, D. B. (2006a). Financing Higher education: Cost-Sharing in International perspective. Boston: Boston College Center for International Higher education and sense Publishers.

Johnstone, D. B., \& Marcucci, P. (2009). Tuition policies in a comparative perspective: Theoretical and political rationales. The Journal of Higher education policy and Management, 29, 161-164.

Johstone, D. B. (2009). An international perspective of the financial fragility of Higher education institutions and systems, Leading stressed colleges and Universities to excellence (pp. 31-48). Baltimore: The Johns Hopkins University press.

Li, W. (2007). Family background, Financial constraints and Higher Education attendance in China. Economics and Education Review, 26, 725-735. http://dx.doi.org/10.1016/j.econedurev.2007.09.001

Macmillan P. (2006). Higher Education in The World, The Financing of Universities. Great Britain, William cloves, First edition. 
Msolla, P. (2007). Issues of Higher Education in Tanzania. Comments at the Joint Japan-World Bank Graduate Scholarship Program. Regional Conference in Dar es salaam. Retrieved from http://www.siteresources.worldbank.org/INTWBISFP/Resources/O_Prof_Msolla.Pdf

Mundel, D. (2008). What do we know about the impact of grants to college students? In S. Baum, M. McPherson, \& P. Steele (Eds), The effectiveness of student aid policies: What the research tells us. Washington, DC: The College Board.

Niu, S. X., \& Tienda, M. (2008). Choosing College: Identifying and modeling choice sets. Social science research, 37, 416-433. http://dx.doi.org/10.1016/j.ssresearch.2007.06.015

Richards, K. (2002). Reforming higher Education student finance in the UK; The impact of recent changes and proposals for the future. The Welsh Journal of Education (Special International Issue), 11(1), 48-63.

Robbins, S. P. (2009). Organizational behaviour; global and Southern African perspectives. Cape Town, Pearson, Education South Africa.

Saunders, M., Lewis, P., \& Thornhill, A. (2007). Research methods for Business students (4th ed.). New York: Prentice Hall.

Shultz, T. W. (1963). The Economic value of Education. New York: Columbia University Press.

Snooks, G. (2008). A general theory of complex living systems: Exploring the demand side of dynamics. Complexity, 13, 12-20. http://dx.doi.org/10.1002/cplx.20225

Somers, P., Haines, K., \& Keene, B. (2006). Toward a theory of choice for community college students. College Journal of Research and Practice, 20, 53-67. http://dx.doi.org/10.1080/10668920500248886

Streitfeld, R. (2009). Unemployment heading back to school. BLUE BELL, Pennsylvania (CNN). Retrieved from http://www.cnn/2009/Living/02/14/unemployement.education/index.html

TCU. (2009). Facts and Figures, Universites and University colleges. Tanzania Commission for Universities, Dar es salaam.

URT. (1998). Financial Sustainability of Higher Education in Tanzania. A report of the task force on Financial Sustainability of Higher Education in Tanzania. Dar es salaam, Ministry of Science, Technology, and Higher Education.

URT. (2005). Review of Financial Sustainability in Financing Higher Education in Tanzania. Dar es Salaam, Ministry of Science, Technology, and Higher Education.

URT. (2007). Basic Statistics on Higher Education 2002/2003-2006/2007. Dar es Salaam: Government Printing Press.

Varghese, N. V. (2006). Growth and Expansion of Private Higher Education in Africa. International Institute of Education Planning, Paris France.

Woodhall, M. (2002a). Student loans: Potential, Problems and Lessons from International Experience Institute of Education. University of London. Institute of Education.

Woodhall, M. (2002b). Paying for learning: The debate on student fees, grants and loans in international perspective. The Welsh Journal of Education.

Woodhall, M. (2007). Funding Higher Education; The contribution of Economic Thinking to Debate and policy development. Washington, DC: World Bank.

World Bank. (2008a). Accelerating catch-up: Tertiary Education for Growth in Subsaharan Africa. World Bank, Washington, DC.

World Bank. (2008b). Project Appraisal Document; Science and Technology Higher Education Program, Tanzania. World Bank, Washington, DC.

World Bank. (2009). World development indicators. World Bank, Washington, DC.

Yang, D. (2006). The ideal and reality of Chinese education equity. Beijing: Peking University Press. 


\section{Appendices}

\section{Appendix I}

A Summary of males \& females Students enrollment in the selected universities

\begin{tabular}{|l|l|l|l|l|l|l|l|l|l|l|l|l|}
\hline \multirow{2}{*}{ Institution } & \multicolumn{2}{|l|}{$2004-2005$} & \multicolumn{2}{l|}{$2005-2006$} & \multicolumn{2}{l|}{$2006-2007$} & \multicolumn{2}{l|}{$2007-2008$} \\
\cline { 2 - 15 } & $\mathrm{F}$ & $\mathrm{M}$ & $\mathrm{T}$ & $\mathrm{F}$ & $\mathrm{M}$ & $\mathrm{T}$ & $\mathrm{F}$ & $\mathrm{M}$ & $\mathrm{T}$ & $\mathrm{F}$ & $\mathrm{M}$ & $\mathrm{T}$ \\
\hline UDSM & 5108 & 7036 & 12144 & 5146 & 9935 & 15081 & 6274 & 12119 & 18393 & 7572 & 13584 & 21156 \\
\hline MZUMBE & 955 & 1595 & 2550 & 1121 & 2089 & 3210 & 1341 & 2133 & 3474 & 1866 & 2571 & 4437 \\
\hline UDOM & 0 & 0 & 0 & 0 & 0 & 0 & 0 & 0 & 0 & 328 & 788 & 1116 \\
\hline SAUT & 287 & 370 & 657 & 503 & 841 & 1344 & 952 & 1713 & 2665 & 1459 & 2706 & 4165 \\
\hline TUDARCO & 137 & 149 & 286 & 108 & 156 & 264 & 575 & 775 & 1350 & 600 & 728 & 1328 \\
\hline Total & 6487 & 9150 & 15637 & 6878 & 13021 & 19899 & 9142 & 16740 & 25882 & 11825 & 20377 & 32202 \\
\hline Female \& Male \% & 41.48 & 58.52 & 100 & 34.56 & 65.44 & 100 & 35.32 & 64.68 & 100 & 37 & 63 & 100 \\
\hline
\end{tabular}

Source: TCU (2009)

\section{Appendix II}

\section{Eligibility for loans in 2007/2008 academic year}

Eligible student for loans in 2007/2008 academic year must meet the following conditions for first degree and Advanced diploma students (HESLB, 2009).

1. Be a Tanzanian (as defined by HESLB Act No 9 of 2004 as amended)

2. Has been admitted to an accredited (recognized) Higher Learning Institution in Tanzania as a candidate for a First Degree or Advanced Diploma on full time basis.

3. A continuing student who has passed the examinations necessary to enable him to advance to the next year or stage of study.

4. A person who is not fully funded by other organizations or sources

5. First time applicants with Division I or II in form six examinations.

6. First time applicants holding an Ordinary Diploma of at least second class grade or an average of "B" scores (if the diploma is not graded) or Full Technician Certificate (FTC) with average of "C" scores.

7. Priority shall be given to applicants admitted to pursue Sciences and Teaching Profession Programmes.

8. An Overseas student under bilateral agreements between the Government of the United Republic of Tanzania and other Governments.

9. Students studying at the Open University of Tanzania for a maximum period of six (6) years. 


\section{Appendix III}

HESLB-SLF 2

\section{HIGHER EDUCATION STUDENTS' LOANS BOARD}

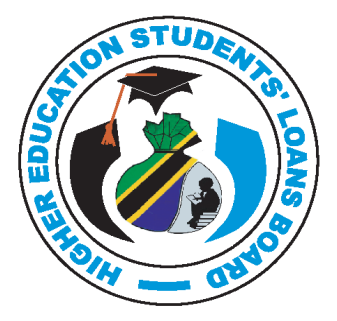

Tirdo Complex, Kimweri Road, Msasani; P.O.Box 76068, Dar es Salaam, Tanzania

Tel: (General) +255 22 2669036/2669037; Fax: +255 22 2669039; E-mail: info@heslb.go.tz; Website: www.heslb.go.tz

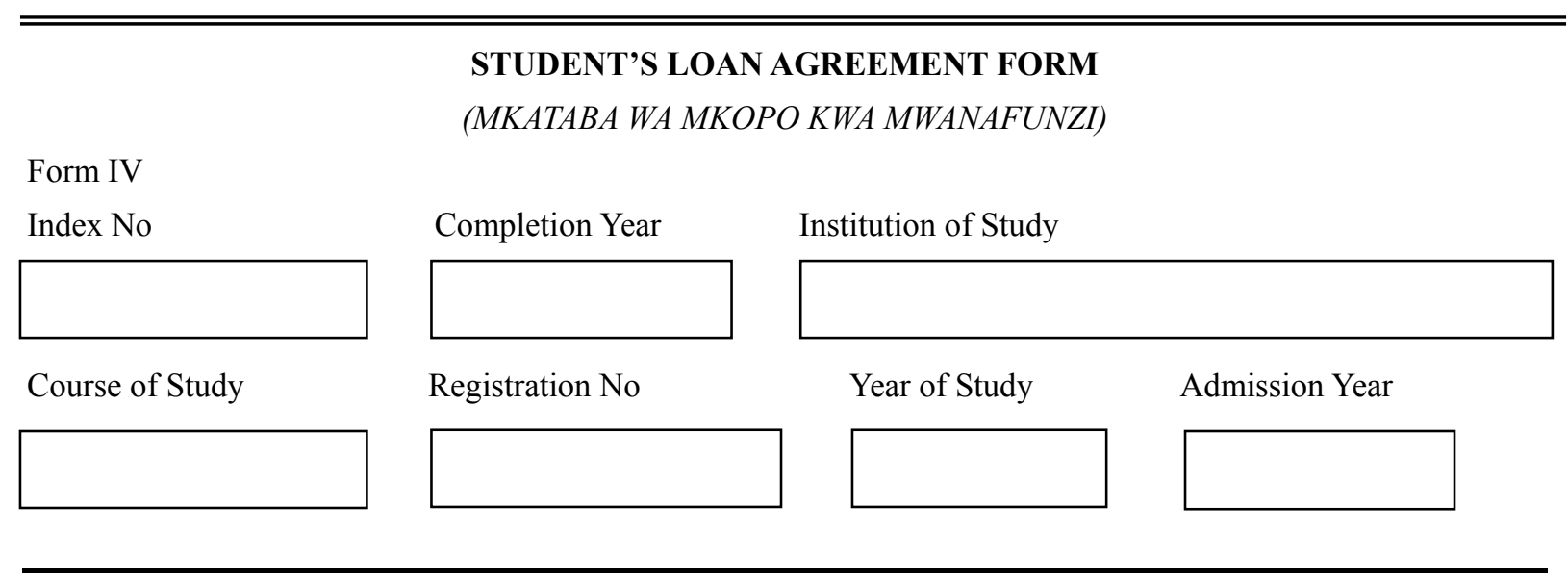

\subsection{Parties to this agreement}

This agreement is being entered into between Higher Education Students' Loans Board of the above appearing address herein referred to as the "Board" and (Mkataba huu ni kati ya Bodi ya Mkopo ya Wanafunzi wa Elimu ya Juu hapa ikijulikana kama "Bodi" (na)

\begin{tabular}{|l|l|}
\hline $\begin{array}{l}\text { Surname } \\
\text { (Jina la Ukoo) }\end{array}$ & \\
\hline First Name & \\
(Jina la Kwanza) & \\
\hline Other Names & \\
(Majina Mengine) & \\
\hline Bank Name & \\
(Jina la Benki) & \\
\hline $\begin{array}{l}\text { Bank Branch } \\
\text { (Tawi la Benki) }\end{array}$ & \\
\hline $\begin{array}{l}\text { Account Number } \\
\text { (Namba ya }\end{array}$ & \\
Akaunti) & \\
\hline
\end{tabular}

Applicants

Passport size

Colour Photo

(Picha ya

Mwombaji

pasipoti ya rangi)

Who in this agreement shall be referred to as the "Student" (ambapo katika mkataba huu atajulikana kama "mwanafunzi") 


\subsection{Terms and Conditions: (Kanuni na Masharti)}

2.1. The students loan agreement forms shall be signed for every fresh loans granted by the Board every academic year but the cumulative amount granted every year shall form part of this agreement. (Fomu za mkataba wa mkopo huu zitasainiwa kila mwaka kwa kiasi cha nyongeza au mafungu ya mkopo ambayo kwapamoja yatakuwa sehemu ya mkataba huu).

2.2. The Contractual amount, consideration of which shall be Tanzanian shilling one thousand only, shall be that amount disbursed by the Board to Bank account of the student and; the amount paid directly to the student through institution of study and; the amount paid by the Board to the bank account of the institution where the student is admitted for studies for the costs related to the student's pursuance of studies and; any subsequent amount as shall be disbursed by the Board. (Kiasi cha mkopo atakachokopeshwa mwanafunzi kwa mujibu wa mkataba huu, kitakuwa ni zile fedha zitakazopelekwa moja kwa moja kwenye akaunti ya Benki ya mwanafunzi na kile kiasi kitakacholipwa taslimu moja kwa moja kwa mwanafunzi kupitia chuo anachosoma, na fedha ambazo zitakazolipwa moja kwa moja kwenye akaunti ya chuo anachosoma mwanafunzi na zile ambazo zitaendelea kulipwa ama kwa mwanafunzi ama kwa chuo zikihusishwa na gharama za masomo ya mwanafunzi).

2.3. The student shall, through the institution of study, update the Board on the academic status of the student immediately upon completion of each academic year and within such reasonable time to allow the Board to process the student's subsequent loan disbursement. (Ni jukumu la mwanafunzi kuijulisha Bodi kuhusu kuendelea kwake na mwaka mpya wa masomo au vinginevyo, kila baada ya mwaka wa masomo kumalizika kupitia chuo anachosoma mwanafunzi, na ndani ya muda wa kutosha kuiwezesha Bodi kuandaa malipo ya mkopo kwa mwaka wa masomo utakaofuata).

2.4. Loan money for tuition fees, special faculty requirements and other institutional costs shall be paid directly to the respective bank account of the institution of study. (Mkopo kwa ajili ya ada ya mafunzo na mahitaji maalumu ya kitivo zitalipwa moja kwa moja katika asasi ya mafunzo inayohusika).

2.5. Approved loan money for student's Direct Costs shall be credited into the student's bank account in instalments or via the institution. (Mkopo unaohusu gharama za mwanafunzi za moja kwa moja utapelekwa kwenye akaunti ya benki ya mwanafunzi kwa awamu ama atapewa mwanafunzi kupitia chuo anachosoma).

2.6. Student's bank account indicated in application form (SLF1 for undergraduate and SLF 4 postgraduate) shall not be changed save with the written consent of the Board upon application by the student. (Akaunti ya mwanafunzi iliyoonyeshwa katika fomu ya maombi ya mkopo (SLF1 kwa shahada ya kwanza na SLF 4 kwa shahada ya uzamili na uzamivu) haitabadilishwa isipokuwa kwa ruhusa ya maandishi kutoka kwa Bodi na baada ya maombi kutoka kwa mwanafunzi).

2.7. The student shall immediately inform the Board of any changes that may affect the loan issuance and/or repayments. The student shall further avail the Board with any further information relating to the loan granted as may be requested by the Board from time to time. (Mwanafunzi anawajibu wa kujulisha Bodi kuhusu mabadiliko yoyote yale yanayoweza kupelekea kuathiri utoaji au urejeshwaji wa mkopo kwa namna yoyote ile. Mwanafunzi pia anawajibu wa kuipatia Bodi taarifa nyingine zozote zile zinazohusiana na mkopo wake pale atakapotakiwa kufanya hivyo na Bodi).

2.8. In view of the loan to be afforded by the Board, the student shall, throughout the course of studies, obey and abide by the by-laws, regulations and directives issued from time to time by the Institution of study. (Kutokana na mkopo utakaokopeshwa na Bodi, Mwanafunzi anawajibika wakati wote wa kipindi cha masomo yake kuheshimu na kutii sheria ndogo za chuo, kanuni na maelekezo yatolewayo mara kwa mara na chuo husika).

2.9. The Board may cancel the loan to a student (Bodi inaweza kusitisha mkopo kwa mwanafunzi):

a) If a student is expelled or is discontinued from his/her Institution of studies (Kama mwanafunzi atafukuzwa au kushindwa kuendelea na masomo kwa kutofaulu katika chuo husika)

b) At the request of the student (Kwa maombi ya mwanafunzi)

c) If he/she neglects his/her studies at the institution (Kama atapuuzia masomo katika chuo anachosoma) 